\title{
Rola sieci społecznych w procesie migracji edukacyjnych przedstawicieli mniejszości litewskiej do litewskich i polskich miast
}

Social networks in Lithuanian minority in Poland and its role in educational migration: The aim of this paper is to explore the social networks of the young generation of Lithuanian minority and the role of social networks in educational migration patterns, both domestic migration and migration to Lithuania. The analysis is based on the ongoing fieldwork conducted among representatives of the Lithuanian minority, inspired by the "multi-sited etnography" tradition. The author discusses the socio-economic and demographic background of the Lithuanian community in Poland, and explains how the migration changes the identification and practices of migrants, with particular attention given to the adaptation process.

Słowa kluczowe: $\quad$ adaptacja, mniejszość litewska, migracje edukacyjne, sieci społeczne, więź etniczna

Keywords: adaptation, Lithuanian minority, educational migrations, social network, ethnic identity

* Doktorantka w Instytucie Socjologii UW • e-mail: kasia.wojcikowska@gmail.com • https://orcid.org/oooo-0002-0911-2266

\section{Wstęp}

Celem artykułu jest analiza roli sieci społecznych w procesie migracji edukacyjnych osób z mniejszości litewskiej w Polsce do polskich i litewskich miast. Moje zainteresowania zawężam do sieci zakorzenionych w społeczności pochodzenia migrantów, czyli obejmujących innych Litwinów z Sejneńszczyzny. Nie omawiam natomiast procesu budowania sieci społecznych wśród przedstawicieli społeczeństwa przyjmującego (w polskich i litewskich miastach). Biorąc pod uwagę ograniczenia dotyczące objętości tekstu, uznałam, że warto dokonać takiego wyboru, ponieważ społeczności mniejszościowe często charakteryzują się odmiennym typem etniczności - intensywniejszym niż grupy funkcjonujące 
jako narody dominujące ${ }^{1}$. Również badacze zajmujący się dotychczas mniejszością litewską podkreślali wyjątkową zwartość tej niewielkiej liczebnie grupy². Można zakładać, że więź etniczna łącząca jej członków pozostaje szczególnie silna. Ciekawe jest zatem, jakie znaczenie ma ona w kontekście mobilności edukacyjnej - zarówno na etapie wyboru studiów, jak i adaptacji w nowym miejscu.

W ostatnich dwóch dekadach w polskiej socjologii i antropologii powstały liczne prace poświęcone migracji potomków osób wysiedlonych lub mieszkańców dawnych Kresów II Rzeczypospolitej do Polski. Badania te obejmowały przede wszystkim młodych ludzi z krajów dawnego ZSRR - Kazachstanu ${ }^{3}$, Litwy, Białorusi i Ukrainy ${ }^{4}$. Koncentrowały się one na doświadczeniu konfrontacji z pozostającą dotychczas przede wszystkim w sferze wyobrażeń „zagraniczną ojczyzną," odczuwanej obcości, trudnościach adaptacyjnych oraz konsekwencjach tych doświadczeń dla przeobrażeń tożsamości. Brakuje natomiast badań dotyczących podobnych migracji wśród przedstawicieli mniejszości narodowych w Polsce. Członkowie mniejszości litewskiej, podobnie jak Polacy ze Wschodu, po roku 1990 mogli liczyć na wsparcie „zagranicznej ojczyzny” w podjęciu studiów ${ }^{5}$, co zapoczątkowało procesy migracji edukacyjnych do Wilna i Kowna. Można przypuszczać, że przynajmniej część ich doświadczeń pozostaje zbliżona do tych zna-

1 E. Nowicka-Rusek, Etniczność a sytuacja mniejszościowa, „Przegląd Polonijny” 1989, nr 15(1), s. 43-57.

2 K. Tarka, Litwini w Polsce 1944-1997, Wydawnictwo Uniwersytetu Opolskiego, Opole 1998; C. Żołędowski, Białorusini i Litwini w Polsce, Polacy na Białorusi i Litwie: uwarunkowania współczesnych stosunków między większością i mniejszościami narodowymi, Oficyna Wydawnicza ASPRA-JR, Warszawa 2003; P. Kalnius, Etniškumo respektavimas šeimoje ir visuomeneje [w:] Punsko ir Seinų krato lietuviai. Etninio ir kultûrinio tapatumo bruožai, red. P. Kalnius, Aušra, Puńsk 2006; S.M. Cervonnaja, Litovcy v Polše: istoriâ i sovremennoe položenie nacional'nogo menšsinstva, Wydawnictwo Mado, Toruń 2009.

${ }_{3}$ Zob. np. P. Hut, Warunki życia i proces adaptacji repatriantów (1992-2000), Instytut Polityki Społecznej UW, Warszawa 2002; H. Grzymała-Moszczyńska, A. Grzymała-Kazłowska, Repatrianci z Kazachstanu - charakterystyka i główne problemy adaptacyjne, Komitet Badań nad Migracjami, Warszawa 2011; M. Wójcik-Żołądek, Obcy wśród swoich? Młodzież polskiego pochodzenia z Kazachstanu studiująca w Polsce, „Studia BAS” 2013, nr 2(34) [Repatrianci i polityka repatriacyjna, red. P. Hut, Ł. Żołądek].

${ }^{4}$ R. Dzwonkowski, O. Gorbaniuk, J. Gorbaniuk, Świadomość narodowa młodzieży polskiego pochodzenia $z$ byłego ZSRR studiującej w Polsce, Towarzystwo Naukowe KUL, Lublin 2002; J. Mucha, Ethnic Polish students from the Former Soviet Union in the homeland of their forefathers. An empirical study, „East European Quarterly” 2003, No 37(2), s. 167-194; Mniejszość polska na rozdrożu: studenci i absolwenci uczelni polskich pochodzacy z Litwy, Białorusi i Ukrainy, red. R. Wyszyński, Instytut Socjologii UW, Warszawa 2005; M. Gońda, Mobilność edukacyjna w sytuacji migracji do korzeni: przypadek młodej polskiej diaspory ze Wschodu, „Studia Migracyjne - Przegląd Polonijny” 2017, nr 1(163), s. 229-258.

5 Zob. V. Bagdonavičiene, The Formation and Development of the Lithuanian Diaspora Policy in 1990-2009, 2012, https://vb.vdu.lt/object/elaba:1723758/1723758.pdf [dostęp: 21 września 2019 r.]. 
nych z przywołanej literatury. W tym kontekście pytanie o rolę sieci społecznych w pokonywaniu doświadczanych barier staje się jeszcze bardziej aktualne.

O ile większość badań koncentruje się wyłącznie na migracjach edukacyjnych młodych ludzi do zagranicznej ojczyzny, o tyle ten artykuł obejmuje zarówno osoby wyjeżdżające na studia do litewskich, jak i polskich miast. Jak zostanie pokazane w dalszej części teksu, z zebranych narracji wynika, że sieci społeczne pozostają zdecydowanie gęstsze w pierwszym z wymienionych przypadków. Potraktowanie relacji migrantów z polskich miast jako materiału porównawczego pozwoli jednak lepiej zrozumieć ich znaczenie dla doświadczenia migracji oraz funkcjonowania w nowym środowisku.

\section{Mniejszość litewska w Polsce i migracje edukacyjne w grupie}

Litwini stanowią jedną z najmniej licznych mniejszości narodowych w Polsce. W ostatnim spisie powszechnym z roku 2011 przynależność do narodu litewskiego zadeklarowały 7863 osoby ${ }^{6}$. Grupa ta ma charakter autochtoniczny znalazła się w granicach państwa polskiego wskutek rozstrzygnięć politycznych po pierwszej wojnie światowej. Do początków XXI wieku charakteryzowała się silną koncentracją terytorialną w północnej części województwa podlaskiego (gminy Puńsk, Sejny i Szypliszki). W tej przestrzennej zwartości badacze upatrywali jednego z głównych źródeł siły jej etniczności ${ }^{7}$. Ostatni spis powszechny pokazał jednak, że współcześnie mniejszość litewska podlega coraz silniejszej presji migracyjnej - związanej zarówno z poszukiwaniem możliwości edukacyjnych, jak i zarobkowych. Zamieszkiwana przez omawianą grupę Sejneńszczyzna to tereny peryferyjne, na których nie ma ważnych ośrodków akademickich, a rynek pracy jest słabo rozwinięty8.

Do lat 90. XX wieku, mimo bliskości terytorialnej, kontakty Litwinów z Polski z ich, wcieloną do Związku Radzieckiego, zagraniczną ojczyzną pozostawały ograniczone. Podróże utrudniała restrykcyjna polityka paszportowa oraz fakt, że do 1992 r. nie było przejścia granicznego między oboma państwami. Podróż na Litwę wymagała przejazdu przez Białoruś i wiązała się z długim oczekiwaniem

${ }^{6}$ W spisie powszechnym w 2011 r. była możliwość deklarowania podwójnych przynależności narodowych. Wśród 7863 osób deklarujących narodowość litewską, ponad 3 tys. zadeklarowały również polską. Trzeba jednak mieć świadomość, że może ona wyrażać raczej poczucie przynależności do państwa zamieszkiwania niż stricte narodu polskiego, zob. R. Suchocka, Meandry etnicznych i narodowych identyfikacji, „Opuscula Sociologica” 2017, No 3(21), s. 5-18.

7 Zob. K. Tarka, Litwini w Polsce 1944-1997, op. cit.; C. Żołędowski, Białorusini i Litwini w Polsce, op. cit.

8 Zob. C. Żołędowski, Białorusini i Litwini w Polsce, op. cit.; M. Barwiński, Geograficzno-polityczne uwarunkowania sytuacji Ukrainców, Łemków, Białorusinów i Litwinów w Polsce po 1944 roku, Wydawnictwo Uniwersytetu Łódzkiego, Łódź 2013, s. 299-300. 
Tabela 1. Liczba absolwentów liceum w Puńsku podejmujących studia w wybranych państwach

\begin{tabular}{|c|c|c|c|}
\hline Rok & $\begin{array}{c}\text { Liczba absolwentów } \\
\text { wybierających studia w Polsce }\end{array}$ & $\begin{array}{c}\text { Liczba absolwentów } \\
\text { wybierających studia } \\
\text { na Litwie }\end{array}$ & $\begin{array}{c}\text { Liczba absolwentów } \\
\text { wybierających studia } \\
\text { w innych państwach }\end{array}$ \\
\hline 1991 & 9 & 3 & 11 \\
\hline 1995 & 8 & 26 & 2 \\
\hline 2000 & 3 & 17 & 8 \\
\hline 2006 & 7 & 17 & 1 \\
\hline 2008 & 7 & 14 & 4 \\
\hline 2010 & 19 & 14 & 6 \\
\hline 2015 & 21 & 9 & 4 \\
\hline
\end{tabular}

Źródło: na podstawie J.S. Paransevičius, M. Černelienė, I. Marcinkevičienė, Punsko kovo11-osios licejui 50, Aušra, Puńsk 2006; A. Krakauskienè, I. Marcinkevičienė, J. Paransevičius, D. Šliaužienė, Punsko kovo11-osios licejui 60, Aušra, Puńsk 2016.

na granicy. Dodatkowo przedstawiciele mniejszości litewskiej, którzy chcieli podjąć studia na Litwie, musieli ubiegać się o miejsce w ramach konkursów skierowanych do wszystkich obywateli polskich starających się o studia w ZSRR. Z możliwości tej korzystało bardzo niewielu młodych ludzi - przede wszystkim ci planujący studia lituanistyczne. Odrodzone państwo litewskie rozpoczęło natomiast aktywną politykę wobec swojej diaspory - nie tylko migrantów, ale także mniejszości w Polsce ${ }^{9}$. Jednym z jej elementów było zachęcanie pochodzącej z niej młodzieży do podejmowania studiów na Litwie poprzez preferencyjne warunki rekrutacji i ofertę stypendialną. Dodatkowo w pierwszej dekadzie XXI wieku pojawiła się możliwość uzyskania przez absolwentów liceum z litewskim językiem nauczania w Puńsku dodatkowych środków z funduszu sponsorowanego przez litewskich emigrantów w USA. Lokalne władze czy organizacje etniczne nie prowadziły nigdy statystyk migracji, jednak szacunki dokonywane przez litewskie liceum pokazują, że przez dwadzieścia lat od odzyskania przez Litwę niepodległości liczba absolwentów wybierających studia na Litwie w stosunku do liczby absolwentów wybierających studia w Polsce wzrastała. W ostatniej dekadzie proporcje te są już bardziej wyrównane ${ }^{10}$, co badani tłumaczyli m.in. niekorzystnymi zmianami warunków rekrutacji, pogorszeniem dostępu i obniżeniem stypendiów oraz wzrostem kosztów życia na Litwie po wejściu kraju do strefy euro. Tabela 1 przedstawia dane dotyczące migracji absolwentów liceum w Puńsku w wybranych państwach ${ }^{11}$.

9 V. Bagdonavičiene, The Formation and Development, op. cit.

10 Zob. J.S. Paransevičius, M. Černelienè, I. Marcinkevičiené, Punsko kovo11-osios licejui 50, Aušra, Puńsk 2006; A. Krakauskienė, I. Marcinkevičienė, J. Paransevičius, D. Šliaužienė, Punsko kovo11-osios licèjui 60, Aušra, Puńsk 2016.

${ }_{11}$ Przedstawione dane są niepełne. W tabeli uwzględniono jedynie absolwentów liceum ogólnokształcącego, a nie funkcjonującego przez pewien czas również liceum profilowanego 
Niezależnie od kierunku migracji oznacza ona jednak dla jednostek opuszczenie małej, dobrze im znanej społeczności oraz konieczność konfrontacji z nowym środowiskiem i przyjęcia pewnej strategii adaptacyjnej.

\section{Inspiracje teoretyczne - sieci społeczne a etniczność}

Moja analiza zakorzeniona jest w dwóch głównych obszarach teoretycznych koncepcjach sieci społecznych (w tym sieci migracyjnych) oraz refleksji na temat etniczności.

Sieci społeczne definiuję za D.T. Gurak i F. Cases jako ustrukturyzowany zbiór powiązań społecznych pomiędzy jednostkami ${ }^{12}$. Powiązania te mogą mieć różny charakter - M. Granovetter wyróżniał więzi silne, cechujące się intensywnością, wzajemnością i trwałością, oraz więzi słabe, cechujące się mniejszym zaangażowaniem i niezakładające silnej zależności i zobowiązań ${ }^{13}$. Oba typy więzi ogrywają inną rolę - zwykle przyjmuje się, że to słabe więzi pozwalają uzyskać dostęp do osób o innym, szczególnie wyższym, statusie społecznym. Kontakt z nimi daje jednostce możliwość uzyskania pewnych, niedostępnych jej dotąd zasobów, a przez to poprawę jej własnej pozycji14.

Problematyka sieci społecznych staje się szczególnie ciekawa w kontekście mobilności. Migrant w nowym środowisku często cechuje się słabszą pozycją społeczną, wynikającą z braku zakorzenienia w społeczności i jej instytucjach oraz ograniczonego kapitału (o różnym charakterze). W sieciach społecznych obecne są natomiast różne zasoby - materialne, symboliczne i emocjonalne ${ }^{15}$, które odpowiednio wykorzystane mogą stanowić kapitał społeczny ${ }^{16}$. Dlatego dostęp do nich oraz umiejętność ich mobilizacji mogą znacznie poszerzać spectrum możliwości działań jednostki i warunkować proces adaptacji w nowym miejscu.

(ze względu na mały odsetek jego absolwentów, który w ogóle wyjeżdżał na studia). Nie ma również podobnych statystyk dotyczących absolwentów liceum w Sejnach, którzy uczyli się litewskiego jako języka dodatkowego i, jak wynika z badań autorki, również niekiedy (choć zdecydowanie rzadziej niż absolwenci z Puńska) wybierali studia na Litwie.

12 D.T. Gurak, F. Cases, Migration networks and the shaping of migration systems [w:] International Migration Systems: A Global Approach, eds. M.M. Kritz, L.L. Lim, H. Zlotnik, Clarendon Press, Oxford 1992, s. 152.

13 M. Granovetter, The strength of weak ties, „American Journal of Sociology” 1973, nr 78, s. 1360-1380.

14 Zob. ibidem; N. Lin, Social Capital. A Theory of Social Structure and Action, Cambridge University Press, Cambridge 2001; M. Kindler, K. Wójcikowska-Baniak, (Missing) Bridging Ties and Social Capital? The Creation and Reproduction of Migrants' Social Network Advantages: The Case of Ukrainian Migrants in Poland, „Central and Eastern European Migration Review" 2019, nr 8(1), s. 95-116.

15 Zob. D.S. Massey et al., Theories of international migration: A review and appraisal, „Population and Development Review" 1993, No 19(3), s. 431-466; N. Lin, Social Capital, op. cit.

${ }^{16}$ N. Lin, Social Capital, op. cit. 
Drugim istotnym punktem odniesienia są dla mnie koncepcje etniczności. Etniczność może być rozumiana na różne sposoby ${ }^{17}$, jednak na potrzeby artykułu uznaję ją za specyficzny typ więzi społecznej - relacji łączącej członków grupy postrzegających się jako odrębnych od innych ${ }^{18}$. Pozostawanie w sytuacji mniejszościowej wskazywane jest przez badaczy, jako czynnik sprzyjający intensyfikacji etniczności ${ }^{19}$ - wynika to z postrzeganej sytuacji zagrożenia własnej odrębności czy słabszej pozycji wobec grupy dominującej. W przypadku mniejszości litewskiej dodatkowym czynnikiem sprzyjającym sile etniczności jest koncentracja terytorialna oraz wysoki stopień zorganizowania $\mathrm{w}$ instytucjach etnicznych - stowarzyszeniach, domach kultury litewskiej oraz szkołach $z$ litewskim językiem nauczania ${ }^{20}$. Można przypuszczać, że silna wieź etniczna przekłada się na funkcjonowanie sieci społecznych - zasięg, ale przede wszystkim intensywność relacji oraz ich znaczenie w procesie migracji.

\section{Metodologia}

Podstawę artykułu stanowią prowadzone przeze mnie w latach 2012-2018 badania wśród osób pochodzących z mniejszości litewskiej na Sejneńszczyźnie, które wyjechały na studia do litewskich lub polskich ośrodków akademickich. Realizowałam je zgodnie z założeniami etnografii wielomiejscowej ${ }^{21}$ - „w punkcie wyjścia badanych", czyli na pograniczu polsko-litewskim (w gminach Puńsk i Sejny), oraz w Warszawie, w Wilnie, Kownie i Połądze.

Główną techniką zbierania danych były wywiady indywidualne z wykorzystaniem elementów biograficznych. Przeprowadziłam również dwa wspólne wywiady z kilkoma osobami dzielącymi mieszkanie, trzy wywiady z małżeństwami oraz wywiad rodzinny - z matką i jej dorosłą córką. W sumie w ramach projektu zrealizowałam 85 wywiadów (różnej długości) z 94 osobami. Wszystkie wywiady prowadziłam w języku polskim - moi rozmówcy byli osobami dwujęzycznymi i swobodnie posługiwali się językiem kraju urodzenia. Do analizy wskazanej problematyki wybrałam jednak jedynie część z nich - 20 wywiadów. Skupiłam się na tych narracjach, w których wątek sieci społecznych był obecny, oraz które, w moim odczuciu, reprezentowały pewne „typy” doświadczenia

17 Zob. G. Babiński, Pogranicze polsko-ukraińskie, Nomos, Kraków 1998.

18 Zob. F. Barth, Grupy i granice etniczne [w:] Badania kultury. Kontynuacje, red. M. Kempny, E. Nowicka, PWN, Warszawa 2004; E. Nowicka-Rusek, Etniczność w świecie współczesnym - Antropolog w działaniu, „Lud” 2003, nr 87, s. 193-203.

19 E. Nowicka-Rusek, Etniczność a sytuacja mniejszościowa, op. cit., s. 43.

20 K. Tarka, Litwini w Polsce 1944-1997, op. cit.; A. Nowakowska, W obronie tożsamości. Organizacje mniejszości litewskiej w Polsce [w:] Litwini, red. L. Nijakowski, Wydawnictwo Sejmowe, Warszawa 2013.

${ }^{21}$ G. Marcus, Ethnography in/of the World System: The Emergence of Multi-Sited Ethnography, „Annual Review of Anthropology” 1995, No 24(1), s. 95-117. 
migracyjnego. Ich wybór wynikał jednak z rozpoznania całości materiału, który stanowił kontekst szczegółowych interpretacji.

Rozmówcy w momencie prowadzenia badań mieli od 20 do 45 lat. Część z nich była jeszcze studentami, przeważali jednak byli absolwenci. Większość z nich pozostała po obronie dyplomu w mieście studiów, część jednak zdecydowała się wrócić do społeczności pochodzenia. W tej drugiej grupie znajdowały się również osoby pełniące funkcje lokalnych liderów - działacze organizacji i instytucji etnicznych.

Badani wyjeżdżali na studia w różnych kontekstach - istotne znaczenie miały uwarunkowania polityczne, ekonomiczne i społeczne, a także związana z nimi obecność innych członków grupy w mieście studiów. Najistotniejszą linią podziału wydaje się wejście Polski i Litwy do Unii Europejskiej w 2004 r., a następnie do strefy Schengen w 2007 r. Otwarcie granic w istotny sposób wpłynęło na swobodę podróżowania, możliwość podtrzymywania relacji ze społecznością pochodzenia, ale także status prawny w zagranicznej ojczyźnie. Ponadto zakres kontaktów z Litwą w okresie dorastania, a zatem wyobrażenie zagranicznej ojczyzny i kraju zamieszkania w momencie wyjazdu na studia pozostawały odmienne wśród młodszych i starszych rozmówców ${ }^{22}$. Wśród 20 szczegółowo analizowanych narracji - 6 rozmówców wyjechało na studia w latach 90 ., 8 rozmówców - w pierwszej dekadzie XXI wieku i 6 rozmówców - w drugiej dekadzie XXI wieku (w tym $4 \mathrm{z}$ nich w momencie prowadzenia badań pozostawało studentami).

Badanie miało charakter jakościowy - jego celem było poznanie i pogłębione zrozumienie doświadczeń badanych. Koncentruję się na tym, jak sami rozmówcy postrzegali swoje, zakorzenione w społeczności pochodzenia, sieci społeczne i jakie znaczenie przypisywali im w procesie migracji. Nie próbuję natomiast dokonywać obiektywizującej rekonstrukcji sieci i weryfikować „prawdziwości” obserwacji i doświadczeń badanych.

\section{Rola sieci społecznych w podejmowaniu decyzji o migracji edukacyjnej}

W narracjach badanych członków mniejszości litewskiej dotyczących ich migracji edukacyjnych, sieci społeczne przedstawiane były jako jeden z kluczowych elementów w procesie wyboru miejsca studiów ${ }^{23}$. Ich znaczenie pozostawało

${ }^{22}$ Mam świadomość, że istotnym kontekstem wpływającym na decyzje migracyjne mogło być wejście Litwy do strefy euro oraz przywoływany przez wielu rozmówców związany z tym wzrost cen na Litwie. Jednakże, moje badania nie objęły pojedynczych osób, które wyjechały na studia dopiero po 2015 roku i nie zostały one włączone do analiz w tym artykule, dlatego nie analizuję szerzej znaczenia tego czynnika.

${ }_{23}$ Zob. D.S. Massey et al., Theories of international migration, op. cit.; L. Ryan, R. Sales, M. Tilki, B. Siara, Social Networks, Social Support and Social Capital: The Experiences of Recent Polish Migrants in London, „Sociology” 2008, No 42(4), s. 672-690. 
jednak odmienne w przypadku wyjazdu na Litwę - czyli zagranicznej ojczyzny oraz wyjazdu na studia do polskiego miasta.

Charakterystyczne jest to, że badani, którzy wybierali studia w Wilnie czy Kownie, wpisywali zwykle swoje decyzje w działania całej zbiorowości. Przedstawiali migrację jako doświadczenie kolektywne. Istotną rolę odgrywały dwa typy sieci społecznych: pierwszy - obejmujący rówieśników ze społeczności pochodzenia, drugi - obejmujący osoby pochodzące z Sejneńszczyzny, lecz studiujące lub pracujące już od pewnego czasu na Litwie.

Pierwszy typ sieci przywoływany był przez niemal wszystkich migrantów na Litwie - niezależnie od czasu wyjazdu. Podobieństwo doświadczeń pokazuje zestawienie wypowiedzi dwóch rozmówczyń. Anastazja ${ }^{24}$, która rozpoczęła studia w Kłajpedzie na samym początku lat 90., wspominała:

„Właśnie i mój rocznik był pierwszym rocznikiem, który miał okazję i prawo studiować na wszystkich wybranych kierunkach w Litwie (...) i jakoś tak wszyscy się rzucili”.

Bardzo podobnie o swoim wyjeździe mówiła ponad 10 lat młodsza Zita, która wyjechała do Kowna w 2003 r.:

„To było 10 lat temu, to nie tak dawno myślę, większość wybierała studia w Litwie. To była taka już tendencja, że 3/4 albo nawet więcej osób wybierało się na Litwę. W ogóle byłam w takiej klasie, że chyba 2 osoby tylko poszły na studia do Polski, a reszta poszliśmy właśnie do Litwy - Kowno, Wilno, główne miasta, gdzie młodzież się wybiera”25.

Dostępne dane - statystyki prowadzone przez liceum z litewskim językiem nauczania w Puńsku - pokazują, że w pierwszych latach po odzyskaniu przez Litwę niepodległości absolwenci tej szkoły nadal częściej wybierali studia w Polsce (tego zdania są również moi rozmówcy, którzy wyjechali wówczas na uczelnię w polskim mieście). Przekonanie pierwszej rozmówczyni, że taką samą decyzję podjęła większość jej znajomych, mogło wynikać z tego, że były to najbliższe jej osoby - najbardziej znaczący inni. Wypowiedzi obu kobiet odzwierciedlają również dominujące w społeczności litewskiej na Sejneńszczyźnie wzorce socjalizacji etnicznej, przekazywane zarówno w rodzinie, jak i w instytucjach etnicznych. Kładły one nacisk na solidarność $\mathrm{i}$ wartość wspólnego działania w ramach gru$\mathrm{py}^{26}$. U podstaw więzi leżało więc przekonanie o konieczności kolektywnego działania - „trzymania się razem”, ale także podzielane doświadczenia i wspomnienia. Pragnienie pozostania w dotychczasowej wspólnocie pokazują słowa Sylwii:

${ }^{24}$ Imiona wszystkich rozmówców zostały zmienione.

25 Wywiady zostały spisane dosłownie, cytowane fragmenty nie były poddane redakcji.

${ }^{26}$ Szerzej o socjalizacji etnicznej piszę w tekście Ethnic Socialisation in the Experiences of Students and Graduates of the Lithuanian Minority in Poland (2014). 
„No i koledzy też tam jechały, koleżanki, koledzy, wszyscy. I jakoś też, na początku chciało się gdzieś razem, żebym nie była sama”.

Ponadto z narracji wielu badanych, szczególnie tych nieco młodszych - urodzonych w połowie lat 80. - wynika, że jako młodzi ludzie odczytywali pewne oczekiwanie ze strony nauczycieli czy rodziców, by wybrać studia na Litwie. Jeden z rozmówców podsumował je słowami:

„Taki jest... jest cały taki obraz prowadzony, że wszystko dobrze mieć, że tylko na Litwie".

Deklarowane przekonanie, że postępuje się „jak większość” członków grupy mogło stanowić zatem swoistą legitymizację decyzji.

Sieci społeczne wśród rówieśników, którzy również wybrali studia na Litwie budowały poczucie bezpieczeństwa - zapewniały wsparcie - przede wszystkim emocjonalne i ograniczały lęk przed niepewnością. Wspólny wyjazd ze znajomymi z jednej klasy, szkoły czy wsi miał szczególne znaczenie dla osób migrujących w latach 90., które nie miały jeszcze rozbudowanej sieci wśród starszych studentów i absolwentów.

Sieci wśród starszych migrantów, czyli typowe sieci migracyjne w rozumieniu Masseya, odgrywały natomiast bardzo istotną rolę w decyzji o wyjeździe na studia do zagranicznej ojczyzny wśród nieco młodszych rozmówców ${ }^{27}$. Okazywały się one istotne $\mathrm{w}$ dwóch wymiarach. Z jednej strony starsi migranci stanowili istotne źródło informacji o warunkach życia i nauki w zagranicznej ojczyźnie. Relacja Kornelii pokazuje, jak przekazy starszych kolegów wpływały na jej wyobrażenie nauki na Litwie:

\footnotetext{
„Chyba ze 3, 4 albo 5 roczników już przede mną studiowało tam właśnie na Litwie i tak opowiadali, że bardzo fajnie, że uczelnie dobre, że zapewniały dobre warunki do zamieszkania, te akademiki i ogólnie mieszkania nie są drogie do wynajmowania i tak po prostu od tych przyjaciół się dowiedziałam, nie wiem czy nawet nie lepsze były te warunki studiować na Litwie niż w Białymstoku”.
}

Informacje i zachęty otrzymywane bezpośrednio od studentów i absolwentów mogły mieć dużą siłę oddziaływania. Narracje osób urodzonych w latach 80. wskazują bowiem, że w okresie dorastania dość rzadko wyjeżdżały one z rodzicami poza Sejneńszczyznę. Wyprawy te utrudniało peryferyjne położenie oraz zaangażowanie rodzin $\mathrm{w}$ pracę $\mathrm{w}$ gospodarstwie rolnym. Młodzi ludzie odwiedzali zagraniczną ojczyznę przede wszystkim w ramach wycieczek organizowanych przez szkołę czy organizacje etniczne, ich znajomość kraju była

${ }^{27}$ Zob. D.S. Massey et al., Theories of international migration, op. cit. 
ograniczona. Informacje od starszych kolegów, postrzegane jako wiarygodne, często stanowily podstawę do podjęcia decyzji. Warto zwrócić uwagę, że istotne mogły być $\mathrm{w}$ tym procesie również więzi stosunkowo słabe - nawet osoby, które nie były dotąd bliskie badanym, w kontekście migracji okazywały się mieć na nich wpływ. Widać to również w narracji Giedre:

\begin{abstract}
„Tylko właśnie mi się bardzo spodobało, bo nauczyciele zrobili pewnego razu takie spotkanie ze studentami, z naszymi studentami stąd, którzy skończyli studia i w Polsce i na Litwie, i oni odpowiadali, jak to jest, które kierunki warto wybrać, który uniwersytet jest fajny i dlaczego. I nie tylko na Litwie, nie tylko w Polsce, ale i na Litwie, żebyśmy mogli... bo niestety, jeżeli mieszkasz w małym - nawet nie miasteczku, tylko wszyscy prawie pochodzimy z wiosek, to jeszcze nie wiemy, jak tam jest, jak te studia wyglądają, więc bardzo fajnie było - mieliśmy cały dzień poświęcony spotkaniu ze studentami i oni nam podpowiadali”.
\end{abstract}

Cytowana rozmówczyni wspominała odbywające się w szkole spotkania ze studentami zarówno z polskich, jak i litewskich miast. Większość rozmówców jednak deklarowała, że częściej uczestniczyli w spotkaniach z osobami mieszkającymi na Litwie (co mogło być konsekwencją przywołanego wcześniej przekonania, że wybór studiów na Litwie był najbardziej pożądanym wzorcem z punktu widzenia grupy).

Z drugiej strony obecność starszych kolegów ograniczała, w odczuciu badanych, ryzyko związane z migracją - wejściem w nowe, nieznane środowisko. Mieli przekonanie, że w razie potrzeby będą mogli zyskać wsparcie od starszych kolegów. Oddają to słowa Gintarasa:

"Tylko zastanawiałem się nad opcjami czy wybrać studia, jakiego rodzaju, a gdzie nie miałem wątpliwości. Wiedziałem, że chcę w Wilnie, właśnie mam kilku znajomych w Wilnie i dlatego wiedziałem, że nie będę miał problemów, gdybym miał jakieś pytania to nie będę miał problemów".

Warto zwrócić uwagę, że wspólne pochodzenie przedstawiane było przez badanego jako podstawa solidarności grupowej ${ }^{28}$. Choć więzi ze starszymi znajomymi w Wilnie były dość słabe, miał przekonanie, że nie odmówią mu pomocy. Prawdopodobnie wynikało ono ze wspomnianych wcześniej, zorientowanych kolektywnie wzorców socjalizacji i wynikającego z nich zobowiązania wobec rodaków z mniejszości.

Badani, którzy wybrali studia w polskich ośrodkach akademickich, zdecydowanie rzadziej przywoływali rolę sieci społecznych w procesie podejmowania

28 A. Portes, J. Sensenbrenner, Embeddedness and immigration: Notes on the social determinants of economic action, „American Journal of Sociology” 1993, No 98(6), s. 1320-1350. 
decyzji o wyjeździe na studia. Część z nich, zwłaszcza rozpoczynający edukację wyższą w pierwszej dekadzie po transformacji, przedstawiała swój wybór jako wpisujący się w dominujące wzorce w grupie (przekonanie, że „większość wybierała studia w Polsce"). Jednakże, zdecydowanie rzadziej stanowiły one czynnik, którym explicite tłumaczyli swoją decyzję. Jedyną osobą, przedstawiającą swój wyjazd do Warszawy jako silnie uwarunkowany wpływem konkretnej osoby był Jokubas:

\begin{abstract}
„Zbliżał się już koniec liceum, właśnie (imię i nazwisko), z którym mieszkałem to mój najlepszy przyjaciel od zerówki, tak naprawdę on jak szedł do Warszawy ja nawet nie myślałem jakoś specjalnie poważnie o Warszawie, ale on tak mówi „Złóż, ja idę. Dobrze będzie". No i jakoś tak z tego żartu obróciło się także że dostałem się tutaj na dzienne studia i to zadecydowało. Bo ani rodzice, ani ja nie mieli pieniędzy (...) No i nie chciałem żadnego kredytu ubrać na studia”.
\end{abstract}

W narracjach Litwinów studiujących w polskich miastach przeważała tendencja do przedstawiania migracji edukacyjnej jako decyzji silnie zindywidualizowanej, czasem - szczególnie wśród młodszych rozmówców - pozostającej w opozycji wobec dominujących wzorców. W niektórych relacjach można nawet wyczytać negatywny wpływ zakorzenionych w społeczności sieci społecznych na wybór miejsca studiów. Dla tych rozmówców wyjazd na polską uczelnię stanowił swego rodzaju „ucieczkę" od silnych więzi w społeczności pochodzenia, uznanych przez nich za ograniczające i utrudniające budowanie nowych relacji, nieopartych na wspólnocie etnicznej.

Nieliczni rozmówcy deklarowali, że w momencie wyjazdu na studia do polskiego miasta mieli już na miejscu swoje sieci migracyjne. Czynnik ten, podobnie jak w przypadku litewskich miast, sprzyjał wyborowi konkretnego ośrodka. Gabija, studentka trzeciego roku, wspominała, że jej zainteresowanie Warszawą zrodziło się dzięki wizytom u siostry:

„Siostra moja, dwanaście lat starsza, więc ja miałam 8, a ona już studiowała... i przyjeżdżałam do niej, do Warszawy, to bardzo widziałam różnicę między Litwą a Warszawą. Tam mi się wydawało tak nowocześnie, tak bogato, że tak powiem... a tam taka bieda trochę".

Warto zwrócić uwagę, że badana mniejsze znaczenie niż migranci na Litwie przypisywała możliwości uzyskania wsparcia (emocjonalnego czy praktycznego). Posiadane sieci, oparte na więziach rodzinnych były dla niej istotne przede wszystkim dlatego, że umożliwiały jej regularne wizyty i poznanie miasta, co stanowiło inspirację do podjęcia nauki w nim. 


\title{
Rola sieci społecznych w procesie adaptacji w mieście studiów
}

Zestawienie narracji migrantów wyjeżdżających na studia do litewskich i do polskich miast wskazuje, że osoby studiujące na Litwie ${ }^{29}$ dysponowały zdecydowanie większymi sieciami społecznymi zakorzenionymi w społeczności pochodzenia niż osoby uczące się w polskich miastach (tendencja ta nie jest jednoznaczna jedynie w przypadku najstarszych rozmówców wyjeżdżających w pierwszych dwóch-trzech latach po rozpadzie Związku Radzieckiego). Wynikało to ze struktury migracji, ale także pewnych rozwiązań instytucjonalnych. $\mathrm{Na}$ Litwie funkcjonują jedynie trzy duże ośrodki akademickie (Wilno, Kowno, Kłajpeda), niemal wszyscy badani wybierali studia w Wilnie i Kownie. Ponadto korzystali z tych samych programów stypendialnych, przez co często byli zakwaterowywani w tych samych akademikach. Środowisko Litwinów z Polski szybko stało się zatem nie tylko dość liczne, ale przede wszystkim - silnie skoncentrowane w dwóch miastach. Badani mieli zatem wiele okazji do regularnych interakcji i wzmacniania więzi ${ }^{30}$. Odzwierciedlają to słowa Kornelii:

\begin{abstract}
„Na początku tam mieszkaliśmy w akademiku, osiem nas chyba było, jeśli dobrze pamiętam i tak mniej więcej cały czas się trzymaliśmy tej grupy, wszyscy z Puńska -z mojego rocznika. Tak mniej więcej na początku wszyscy jednej kupy się trzymaliśmy - czy na zakupy, czy na jakieś dyskoteki, czy na zajęcia, wszyscy razem taką chmarą jeździliśmy”.
\end{abstract}

Ze względu na znacznie większą liczbę uczelni studenci litewskiego pochodzenia w Polsce pozostawali zdecydowanie bardziej rozproszeni. Często deklarowali, że znali w mieście studiów jedynie pojedyncze osoby, które nie należały do grona ich bliskich znajomych. Brak sprzyjającego kontekstu do regularnych interakcji powodował, że zwykle z czasem więzi te ulegały dalszemu osłabieniu.

Zakorzenione w społeczności pochodzenia sieci społeczne badanych migrantów były dość homogeniczne - nie tylko, co oczywiste, pod względem narodowości, ale także wykształcenia czy statusu socjoekonomicznego. Wynika to $\mathrm{z}$ charakterystyki mniejszości litewskiej w Polsce - jest to grupa niewielka,

${ }^{29}$ Współcześnie coraz częściej pojawiają się głosy krytyczne wobec formy „na Litwie” lub „na Litwę”. Przyimek „na” stosowany jest wobec państw, które w przeszłości stanowiły terytoria zależne i może być interpretowany jako symboliczne wyrażanie relacji podległości. Wielu moich rozmówców preferuje stosowanie formy „w Litwie” i „do Litwy” (co widać w części przywoływanych cytatów). Zależy mi, by podkreślić perspektywę badanych i dać wyraz poparcia ich postulatom. Wobec toczącej się dyskusji dotyczącej obu form, ze względów redakcyjnych pozostaję jednak przy przyjętej w języku polskim i niepodważanej dotąd przez językoznawców formie „na”.

${ }_{30}$ Zob. M. Eve, Integrating via networks: foreigners and others, „Ethnic and Racial Studies” 2010, No 33(7), s. 1231-1248. 
mieszkająca na terenach wiejskich, zajmująca się głównie rolnictwem. Stąd też - mimo pewnego wewnętrznego zróżnicowania (dostrzeganego przez moich badanych), migranci mieli podobne cechy, jeśli chodzi np. o posiadany kapitał kulturowy, sieci kontaktów czy, w znacznej mierze, również kapitał ekonomiczny. Elementem różnicującym pozostawał przede wszystkim czas spędzony w mieście studiów i związane z tym doświadczenie. Naukowcy wskazują, że im większa heterogeniczność sieci (czyli różnorodność jej członków), tym silniejszy jest tzw. efekt sieciowy i możliwość dotarcia do zasobów odmiennych od posiadanych przez nas ${ }^{31}$. Jednakże, choć sieci badanych członków mniejszości litewskiej pozostawały dość homogeniczne, analiza zebranych narracji pokazuje, że miały one kluczowe znaczenie w procesie adaptacji w mieście studiów. Obecne w nich były bowiem, cenne z punktu widzenia badanych zasoby - przede wszystkim niematerialne. Nieprzypadkowo piszę o procesie adaptacji, a nie integracji. Stosowanie pojęcia „integracja” sugeruje pragnienie pozostania w mieście studiów i włączenie w nową społeczność. Tymczasem było to dążenie jedynie pewnej grupy rozmówców, inni traktowali migrację edukacyjną jako tymczasową i planowali powrót do społeczności pochodzenia lub łączenie zaangażowania w społeczności pochodzenia i nowym miejscu (poprzez praktyki transnarodowe). Pojęcie adaptacji jest szersze - zakłada różne cele i modele radzenia sobie przez jednostkę z nowym środowiskiem i wyzwaniami temu towarzyszącymi ${ }^{32}$.

W dalszej analizie odwołuję się do podziału C. Schaefera, wyróżniającego trzy formy wsparcia, które można uzyskać w sieciach i które mogą stanowić kapitał społeczny - informacyjne, emocjonalne i instrumentalne ${ }^{33}$. Każde z nich redukowało inne bariery doświadczane przez młodych Litwinów po migracji edukacyjnej.

\section{Wsparcie informacyjne}

Wsparcie informacyjne obejmuje dzielenie się wiedzą, doświadczeniami, a także udzielanie informacji zwrotnej na temat postępowania migrantów przez osoby lepiej znające kontekst społeczeństwa przyjmującego ${ }^{34}$. Jak zostało pokazane w poprzedniej części artykułu, wsparcie informacyjne ze strony starszych kolegów i koleżanek odgrywało bardzo istotną rolę już na etapie wyboru kraju studiów i uczelni. Narracje badanych sugerują, że po ich przyjeździe do miasta starsi koledzy, szczególnie na Litwie, wchodzili w rolę tzw. gatekeeperów, stając się przewodnikami po nowej rzeczywistości, zarówno na uczelni, jak i w mie-

31 N. Lin, Social Capital, op. cit.

32 A. Grzymała-Kazłowska, Integracja - próba rekonstrukcji pojęcia [w:] A. Grzymała-Kazłowska, S. Łodziński, Problemy integracji migrantów. Koncepcje, badania, polityki. Wydawnictwa Uniwersytetu Warszawskiego, Warszawa 2008, s. 41.

${ }_{33}$ C. Schaefer, J. Coyne, R. Lazarus, The Health-Related Functions of Social Support, „Journal of Behavioral Medicine" 1981, nr 4(4), s. 381-405.

${ }^{34}$ Ibidem, s. 386. 
ście. Nie zawsze były to osoby, z którymi łączyły ich bliskie relacje jeszcze na Sejneńszczyźnie. W nowym kontekście wspólne pochodzenie etniczne stawało się podstawą do podtrzymywania i wzmacniania relacji oraz udzielania wsparcia. Uwewnętrznione poczucie solidarności, którego źródłem była prawdopodobnie silna więź etniczna, wyrażają słowa Arunasa:

\begin{abstract}
„My potem też staraliśmy się młodszym pomóc przy załatwieniu akademika, stypendiów różnego rodzaju, także taka była solidarność tych Litwinów z Polski, którzy szli na studia - starszych z pierwszoroczniakami. Także też, że byłem jeden chłopak i jedna dziewczyna w tym akademiku, stąd to musieliśmy rad niewola być z tymi naszymi sąsiadami, kolegami z roku, także te przyjaźnie się porobiły, żeśmy się fajnie polubili”.
\end{abstract}

Migranci wspominali, że „odnalezienie się" na studiach stanowiło duże wyzwanie. Część trudności wynikała z przejścia na wyższy poziom edukacji, część była uwarunkowana odmiennym system edukacji w Polsce i na Litwie oraz przejściem z małej, wiejskiej społeczności do dużego miasta. Badani studiujący w litewskich miastach uzyskiwali od starszych członków mniejszości praktyczne informacje na temat studiowania - porady w kwestii wyboru prowadzących zajęcia, układania planu. Relacja Giedre oddaje poczucie zagubienia oraz znaczenie więzi społecznych przy próbie uporządkowania doświadczanego chaosu:

\footnotetext{
„Tak z początku zawsze wszyscy trzymaliśmy się tutaj, nasza paczka stąd i właśnie schodziliśmy się ze studentami starszymi, którzy byli na drugim-trzecim roku czy na studiach magisterskich, także oni podpowiadali, jak ułożyć plan zajęć, bo to była masakra na początku, jak ten plan ułożyć dobrze, jak zarejestrować się w bibliotece, bo tam biblioteka ogromna, wszystko załatwia się poprzez komputer i Internet, to też zupełnie inaczej było, także z początku było trudno, ale bardzo nam pomogli studenci tutaj od nas, więc było wszystko w porządku już potem".
}

Starsi koledzy byli również źródłem wiedzy na temat funkcjonowania w dużym mieście. Pochodzący ze wsi badani często przywoływali poczucie obcości w nowej przestrzeni - wynikającej z braku zarówno rozpoznanych, ważnych miejsc, jak i doświadczenia w korzystaniu z pewnych usług (np. codziennego poruszania się komunikacją miejską). Cytowany już Arunas wspominał wsparcie, które uzyskał od innych Litwinów z Sejneńszczyzny w procesie oswajania miasta:

„Bardzo często się spotykaliśmy z kolegami z Puńska, tu z liceum, to tego... też ze starszymi, którzy już studiowali w Kownie, mieli jakieś doświadczenie, mogli podpowiedzieć, co, jak, jakimi autobusami, gdzie dojechać. To też takie ułatwienia były”.

Podobne doświadczenia odnajdujemy w narracji Ruty: 
„Brat mi dużo pomógł, bo poodwoził, tam razem jeździliśmy, zobaczyliśmy jak tutaj dojść czy tutaj gdzieś”.

Pochodzący z mniejszości badani Litwini, którzy wybrali studia w Polsce, bardzo rzadko wspominali w swoich wypowiedziach tego rodzaju wsparcie. Część z nich, przyjeżdżając na studia, nie znała w mieście nikogo ze społeczności pochodzenia, część - pojedyncze osoby, studiujące na innych kierunkach lub uczelniach. Zestawienie wcześniejszych wypowiedzi z relacją Rasy, która rozpoczęła studia w Poznaniu w drugiej połowie lat 90., nie znając tam nikogo wyraźnie pokazuje znaczenie sieci społecznych dla doświadczania migracji:

„Nie wsiadłam w tą stronę do tramwaju, co powinnam była... bo nie wiedziałam, że to w dwie strony jeździ. Wiem, że nogi to gąbki były... Weź się znajdź... nigdy nie jeździłaś tramwajem, nie wiesz, gdzie się bilety kupuje, jakiego rodzaju bilety są... ulgowe, nie ulgowe. (...), gdzie ja ci te bilety ulgowe kupię w Puńsku czy Suwałkach. Daj spokój. I to na transport miejski, prawda. To było duże przeżycie. Rzeczywiście jak rzucona absolutnie [na głęboką wodę - dopisek K.W.-B.]. I wiesz jeszcze szukanie, słuchaj, stancji tzw. kurczę... że dzwonić trzeba... i jeszcze żarcie... (...)... Zwierzyniecka ulica, akademik studencki... wiesz, żeby sobie miejsce zająć. Ale się bardzo obco czułam, no bo nikogo nie znałam".

Przywoływane przez Rasę doświadczenie trudności w odnalezieniu się w mieście obecne było również w narracjach migrantów, wyjeżdżających na studia na Litwę. Brak sieci społecznych zakorzenionych w społeczności pochodzenia sprawiał natomiast, że badani silniej przeżywali zmianę związaną z przejściem ze wsi do miasta. Z drugiej strony jednak, ze względu na brak wsparcia i konieczność przyjęcia silnie zindywidualizowanych strategii, szybciej zaczynali w nich samodzielnie funkcjonować.

\section{Wsparcie emocjonalne}

Wsparcie emocjonalne wiązane jest w literaturze przede wszystkim ze wzajemną troską, poczuciem przynależności, zainteresowaniem, empatią, współczuciem ${ }^{35}$. Narracje pochodzących z mniejszości litewskiej migrantów edukacyjnych wskazują, że kluczowe znaczenie w wymiarze emocjonalnym miało dla nich same spędzanie czasu w ramach grupy pochodzenia, które w znacznym stopniu rekompensowało doświadczane bariery. Trzeba przy tym podkreślić, że bariery te były odmienne wśród osób studiujących w kraju zamieszkania i w zagranicznej ojczyźnie.

Dla badanych wybierających uczelnie na Litwie jednym z najtrudniejszych doświadczeń była konfrontacja wyobrażonego, wyidealizowanego obrazu ojczy-

35 C. Schaefer, J. Coyne, R. Lazarus, The Health-Related Functions, op. cit., s. 385. 
stego kraju i rodaków z zastaną po migracji rzeczywistością. Zamieszkanie na Litwie i kontakt z jej mieszkańcami uświadamiał im różnice kulturowe, wynikające $z$ odmiennych warunków funkcjonowania ich grupy pochodzenia, a co za tym idzie - także uwarunkowań ich biografii. Ponadto również Litwini na Litwie często nie rozumieli ich historii, kategoryzując ich jako „Polaków” lub litewskich emigrantów.

Doświadczenie to, opisywane też przez badaczy w odniesieniu do Polaków ze Wschodu przybywających do Polski na studia lub w ramach repatriacji ${ }^{36}$, stawało się źródłem obcości. W związku z tym znaczna część rozmówców przez cały okres studiów utrzymywała relacje przede wszystkim, a niekiedy niemal wyłącznie, z członkami własnej grupy pochodzenia - dotychczasowe więzi ulegały wzmocnieniu. W kontaktach tych odnajdywała bezpieczeństwo i poczucie swojskości. Pokazują to słowa Alicji, która mówiła o koleżankach z Sejneńszczyzny, z którymi dzieliła mieszkanie w akademiku:

„Także my naprawdę miałyśmy swojskie życie tam. I to z pewnością też dawało takie Puńsk jest ze mną... takie wiesz, nie pozwalało się oderwać samotnie, bo jak jesteś wśród swoich, to wiesz, co się dzieje, Ty wiesz, kiedy, jaki koncert, czy coś razem organizujemy, czy co jest fajne".

Doświadczenie wyjątkowego zrozumienia i zaufania wynikało zarówno z podzielania znacznej części biografii, jak i możliwości odtwarzania wspólnych kodów kulturowych - swobodnego posługiwania się lokalnym dialektem, odmiennym od standardowego języka litewskiego czy słuchania muzyki ludowej. Relacja Zity odzwierciedla poczucie swojskości przeżywane wśród znajomych z Sejneńszczyzny, które minimalizowało cierpienia związane z obcością, odczuwaną wśród rodaków, urodzonych i dorastających w zagranicznej ojczyźnie:

„Pamiętam w akademiku wiesz, imprezy, jakieś po sesjach, po czymś - to puńskowska impreza wygląda tak - zawsze musi być akordeon, stara dobra litewska piosenka, śpiewana na głosy, wiesz, to musi być hucznie, fajnie, wesoło, z tańcami”.

${ }^{36}$ H. Grzymała-Moszczyńska, A. Grzymała-Kazłowska, Repatrianci z Kazachstanu, op. cit.; J. Mucha, Ethnic Polish students from the Former Soviet Union, op. cit.; M. Wójcik-Żołądek, Obcy wśród swoich?, op. cit.; Mniejszość polska na rozdrożu, op. cit.; M. Głowacka-Grajper, Program stypendialny w ocenie jego uczestników. Absolwenci z Białorusi, Litwy i Ukrainy o swoich studiach i obecnej sytuacji po powrocie do kraju zamieszkania [w: ] Mniejszość polska na rozdrożu: studenci i absolwenci uczelni polskich pochodzących z Litwy, Białorusi i Ukrainy, red. R. Wyszyński, Instytut Socjologii UW, Warszawa 2005; M. Gońda, Biographical Pathways of Roots Migration: the Case of Students of Polish Ancestry from the Post-Soviet Area, „Polish Sociological Review" 2015, No 1(189), s. 69-84. 
Badani studiujący w polskich miastach zdecydowanie rzadziej przywoływali w swoich narracjach poczucie obcości. Przeciwnie, wyjeżdżając często spodziewali się zetknięcia z istotnymi różnicami kulturowymi czy obawiali się stosunku Polaków wobec siebie. Po migracji zwykle odkrywali natomiast, że więź kulturowa, która łączy ich z Polakami, jest silna i stanowi podstawę do swobodnego funkcjonowania, a ich pochodzenie i samookreślenie spotyka się z akceptacją, a nawet życzliwym zainteresowaniem. Jednakże i dla nich sieci zakorzenione w społeczności pochodzenia pozostawały istotne. Najwyraźniej widać to w relacji Ramunasa, który wyjechał na studia do Białegostoku w połowie lat 90. Jego narracja wyróżniała się na tle narracji innych migrantów z polskich miast, bliższa była relacjom badanych uczących się na Litwie. Prawdopodobnie wynikało to z faktu, że w omawianym okresie środowisko litewskich studentów w Białymstoku był jeszcze dość liczne:

\begin{abstract}
„Ja pamiętam tak z 10-20 osób, z którymi utrzymywałem kontakty z Puńska... w Białymstoku. (...) bardzo zżyci byliśmy w tym liceum. (...). My bardzo dużo czasu spędzaliśmy razem z tymi... i dlatego... to było tak bardziej naturalne, ja już tych ludzi znałem, są w porządku, itd. ... może to tak była niechęć do wyjścia z tej mniejszości... z tej sfery komfortu, że tych ludzi już znasz... i oni tam przewidywalni tam są i niektórzy tam... (...). I to byli naprawdę bardzo dobrzy ludzie, przyjaciele i dlatego tak bardziej naturalnie z nimi, cały czas. Także to był bardzo naturalny wybór, by trzymać się z nimi... może ten moment, że oni też należeli do tej mniejszości litewskiej... może też to poczucie wspólnoty i powiedzmy, że oni też są tacy sami, to człowiek bardziej naturalnie chyba, nie wiem, lubi ludzi podobnych do siebie... większość ludzi... bardziej przyciągają ludzi podobnych do siebie".
\end{abstract}

W cytowanym fragmencie zwraca uwagę powtarzane słowo "naturalne”, stanowiące prawdopodobnie dla badanego synonim swojskości. Silne więzi z osobami z Sejneńszczyzny zapewniały mu emocjonalne wsparcie i poczucie bezpieczeństwa w nowym środowisku. Kluczowe znaczenie miała świadomość podzielania tych samych doświadczeń - zarówno przed, jak i po migracji i wynikające $\mathrm{z}$ tego wzajemne zrozumienie.

Zakorzenione w społeczności pochodzenia sieci społeczne pozostałych badanych z polskich miast były znacznie mniejsze. Zwykle nie stanowiły dla nich jedynej czy nawet dominującej grupy towarzyskiej. Więzi z rodakami pozostawały jednak ważne, zapewniały bowiem kontakt $\mathrm{z}$ kulturą grupy pochodzenia oraz ojczystym językiem. Studiująca w Poznaniu Lina mówiła o znaczeniu relacji z koleżanką, z którą dzieliła mieszkanie: 
Relacje $\mathrm{z}$ osobami z grupy pochodzenia gwarantowały zatem poczucie ciągłości w wymiarze biograficznym, ale i tożsamościowym - ułatwiały zdefiniowanie siebie jako członka mniejszości w nowym kontekście - poza zwartą społecznością etniczną.

\section{Wsparcie instrumentalne}

Wsparcie instrumentalne w rozumieniu C. Schaefera obejmuje np. pomoc materialną, finansową, pożyczki, udostępnienie własnych zasobów czy wykonanie pewnych usług, np. opiekuńczych ${ }^{37}$. W zebranym materiale ten rodzaj wsparcia jest najrzadziej przywoływany przez badanych, niezależnie od kierunku migracji. Wynika to z charakteru sieci i wspomnianej już wcześniej homogeniczności. Wsparcie instrumentalne z większym prawdopodobieństwem można uzyskać od osób o wyższym statusie, dysponujących większym kapitałem - przede wszystkim społecznym czy ekonomicznym. Migranci mieli w swoich sieciach natomiast przede wszystkim osoby o pozycji podobnej do własnej, a zatem możliwości uzyskania tego typu wsparcia pozostawały ograniczone. Niemniej można zidentyfikować kilka form praktycznego wsparcia przywoływanego przez rozmówców, przede wszystkim migrujących na Litwę. Należało do nich na przykład dzielenie się z rodakami z Sejneńszczyzny produktami przywiezionymi z domu, wspólne gotowanie, w razie potrzeby - goszczenie w mieszkaniu lub pokoju. Asta wspominała czas studiów:

„Jedni u drugich nocowaliśmy, kolegowaliśmy się do takiego stopnia, że obiady razem gotowaliśmy, wszystko. Co z domu rodzice dawali, jakieś tam jedzenie, cały czas wszystko gotowaliśmy razem".

Powszechną formą wzajemnego wsparcia były również wspólne podróże powrotne do Polski. Osoby dysponujące samochodami, wyjeżdżając na weekendy czy wakacje, często zabierały ze sobą znajomych ze społeczności pochodzenia.

Badani absolwenci o stabilnej pozycji zawodowej, mówiąc o relacjach z rodakami z Polski, często wskazywali na wyjątkowe zaufanie, którymi ich darzą. Wyrażali przekonanie, że gdyby mieli możliwość, chętnie wsparliby np. przyjęcie takiej osoby do pracy. Dotyczyło ono również osób, których nie znali bezpośrednio, a zatem ponownie źródłem była solidarność grupowa, a nie osobiste doświadczenie ${ }^{38}$. Kilka starszych rozmówczyń, które miały już swoje dzieci, zatrudniało natomiast studentki z grupy pochodzenia jako nianie. Wydaje się zatem, że więzi etniczne mogą być również czynnikiem ułatwiającym znalezienie pracy, choć $\mathrm{z}$ racji ograniczonej wielkości grupy - jedynie w wybranych segmentach rynku.

37 Zob. C. Schaefer, J. Coyne, R. Lazarus, The Health-Related Functions, op. cit., s. 385-386.

38 A. Portes, J. Sensenbrenner, Embeddedness and immigration, op. cit. 


\section{Podsumowanie}

Silna więź etniczna łącząca mniejszość litewską na pograniczu zachowuje swoją aktualność również w sytuacji migracji edukacyjnej jej członków - po opuszczeniu przez nich zwartej, mocno związanej z terytorium społeczności pochodzenia. Zakorzenione w niej sieci społeczne są dla młodych migrantów wyjeżdżających na studia źródłem zasobów - szczególnie niematerialnych informacyjnych, emocjonalnych, symbolicznych. Ponieważ badani migranci potrafią je łatwo zmobilizować do realizacji własnych celów, przekładają się na posiadany przez nich kapitał społeczny ${ }^{39}$. Podstawą udostępniania wskazanych zasobów jest poczucie grupowej solidarności, ukształtowane w toku socjalizacji etnicznej. Rola sieci społecznych wydaje się istotniejsza w przypadku migracji do zagranicznej ojczyzny niż do polskich miast, co spowodowane jest w znacznym stopniu czynnikami strukturalnymi (wielkość migracji, liczba ośrodków akademickich, wsparcie instytucjonalne). Omawiane sieci mogą ułatwiać młodym migrantom proces adaptacji w nowym miejscu - rekompensując negatywne doświadczanie różnego typu barier związanych z przejściem ze wsi do miasta, odmiennością kulturową czy poczuciem wykorzenienia. Jednak gęste sieci zakorzenione w społeczności pochodzenia i możliwość uzyskania w nich wielu rodzajów wsparcia mogą ograniczać motywację do nawiązywania relacji z mieszkańcami w nowym miejscu i tworzenia tzw. więzi pomostowych, łączących ich z osobami spoza własnej sieci i środowiska pochodzenia - mniej angażujących, lecz zapewniających dostęp do innego typu kapitałów i ułatwiających wejście w instytucje społeczności przyjmującej. Sprzyjają zatem raczej adaptacji do sytuacji migracyjnej lub funkcjonowania między społecznością pochodzenia i społecznością przyjmującą niż adaptacji do społeczeństwa przyjmującego.

\section{Bibliografia}

Babiński G., Pogranicze polsko-ukraińskie, Nomos, Kraków 1998.

Bagdonavičiene V., The Formation and Development of the Lithuanian Diaspora Policy in 1990-2009, 2012, https://vb.vdu.lt/object/elaba:1723758/1723758.pdf.

Barth F., Grupy i granice etniczne [w:] Badania kultury. Kontynuacje, red. M. Kempny,

E. Nowicka, PWN, Warszawa 2004.

Barwiński M., Geograficzno-polityczne uwarunkowania sytuacji Ukraińców, Łemków, Białorusinów i Litwinów w Polsce po 1944 roku, Wydawnictwo Uniwersytetu Łódzkiego, Łódź 2013.

Cervonnaja S.M., Litovcy v Pol'še: istoriâ i sovremennoe položenie nacional’nogo menšsinstva, Wydawnictwo Mado, Torun 2009.

39 Zob. N. Lin, Social Capital, op. cit. 
Dzwonkowski R., Gorbaniuk O., Gorbaniuk J., Świadomość narodowa młodzieży polskiego pochodzenia z byłego ZSRR studiującej w Polsce, Towarzystwo Naukowe KUL, Lublin 2002.

Eve M., Integrating via networks: foreigners and others, „Ethnic and Racial Studies” 2010, No 33(7).

Głowacka-Grajper M., Program stypendialny w ocenie jego uczestników. Absolwenci $z$ Białorusi, Litwy i Ukrainy o swoich studiach i obecnej sytuacji po powrocie do kraju zamieszkania [w: ] Mniejszość polska na rozdrożu: studenci i absolwenci uczelni polskich pochodzacych z Litwy, Białorusi i Ukrainy, red. R. Wyszyński, Instytut Socjologii UW, Warszawa 2005.

Gońda M., Biographical Pathways of Roots Migration: the Case of Students of Polish Ancestry from the Post-Soviet Area, „Polish Sociological Review” 2015, No 1(189).

Gońda M., Mobilność edukacyjna w sytuacji migracji do korzeni: przypadek młodej polskiej diaspory ze Wschodu, „Studia Migracyjne - Przegląd Polonijny” 2017, nr 1(163).

Granovetter M., The strength of weak ties, „American Journal of Sociology” 1973, No 78.

Grzymała-Kazłowska A., Integracja - próba rekonstrukcji pojęcia [w:] A. Grzymała-Kazłowska, S. Łodziński, Problemy integracji migrantów. Koncepcje, badania, polityki. Wydawnictwa Uniwersytetu Warszawskiego, Warszawa 2008.

Grzymała-Moszczyńska H., Grzymała-Kazłowska A., Repatrianci z Kazachstanu - charakterystyka i główne problemy adaptacyjne, Komitet Badań nad Migracjami, Warszawa 2011.

Gurak D.T., Cases F., Migration networks and the shaping of migration systems [w:] International Migration Systems: A Global Approach, eds. M.M. Kritz, L.L. Lim, H. Zlotnik, Clarendon Press, Oxford 1992.

Hut P., Warunki życia i proces adaptacji repatriantów (1992-2000), Instytut Polityki Społecznej UW, Warszawa 2002.

Kalnius P., Etniškumo respektavimas šeimoje ir visuomeneje [w:] Punsko ir Seinu krato lietuviai. Etninio ir kultûrinio tapatumo bruožai, red. P. Kalnius, Aušra, Puńsk 2006.

Kindler M., Wójcikowska-Baniak K., (Missing) Bridging Ties and Social Capital? The Creation and Reproduction of Migrants' Social Network Advantages: The Case of Ukrainian Migrants in Poland, „Central and Eastern European Migration Review” 2019, No 8(1).

Krakauskienė A., Marcinkevičienė I., Paransevičius J., Šliaužienė D., Punsko Kovo 11-osios licèjui 60, Aušra, Puńsk 2016.

Lin N., Social Capital. A Theory of Social Structure and Action, Cambridge University Press, Cambridge 2001.

Massey D.S. et al., Theories of international migration: A review and appraisal, „Population and Development Review" 1993, No 19(3).

Marcus G., Ethnography in/of the World System: The Emergence of Multi-Sited Ethnography, „Annual Review of Anthropology” 1995, No 24(1).

Mniejszość polska na rozdrożu: studenci i absolwenci uczelni polskich pochodzacych z Litwy, Białorusi i Ukrainy, red. R. Wyszyński, Instytut Socjologii UW. Warszawa 2005. 
Mucha J., Ethnic Polish students from the Former Soviet Union in the homeland of their forefathers. An empirical study, „East European Quarterly” 2003, No 37(2).

Nowakowska A., W obronie tożsamości. Organizacje mniejszości litewskiej w Polsce [w:] Litwini, red. L. Nijakowski, Wydawnictwo Sejmowe, Warszawa 2013.

Nowicka-Rusek E., Etniczność a sytuacja mniejszościowa, „Przegląd Polonijny” 1989, nr 15(1).

Nowicka-Rusek E., Etniczność w świecie współczesnym - Antropolog w działaniu, „Lud” 2003, nr 87.

Paransevičius J.S., Černelienè M., Marcinkevičienė I., Punsko kovo11-osios licèjui 50, Aušra, Puńsk 2006.

Portes A., Sensenbrenner J., Embeddedness and immigration: Notes on the social determinants of economic action, „American Journal of Sociology” 1993, No 98(6).

Portes A., Social capital: its origins and applications in modern sociology, „Annual Review of Sociology" 1998, No 24.

Ryan L., Sales R., Tilki M., Siara B., Social Networks, Social Support and Social Capital: The Experiences of Recent Polish Migrants in London, „Sociology” 2008, No 42(4).

Ryan L., Migrants' social networks and weak ties: accessing resources and constructing relationships post-migration, „The Sociological Review” 2011, No 59(4).

Schaefer C., Coyne J., Lazarus R., The Health-Related Functions of Social Support, „Journal of Behavioral Medicine" 1981, No 4(4).

Suchocka R., Meandry etnicznych i narodowych identyfikacji, „Opuscula Sociologica” 2017, nr 3(21).

Tarka K., Litwini w Polsce 1944-1997, Wydawnictwo Uniwersytetu Opolskiego, Opole 1998.

Wójcik-Żołądek M., Obcy wśród swoich? Młodzież polskiego pochodzenia z Kazachstanu studiujaca w Polsce, „Studia BAS” 2013, nr 2(34) [Repatrianci i polityka repatriacyjna, red. P. Hut, Ł. Żołądek].

Żołędowski C., Białorusini i Litwini w Polsce, Polacy na Białorusi i Litwie: uwarunkowania współczesnych stosunków między większością i mniejszościami narodowymi, Oficyna Wydawnicza ASPRA-JR, Warszawa 2003. 